\title{
Pendalaman Konsep Geometri dan Pembuatan Media Pembelajaran Bagi Guru-Guru SD Kota Soe
}

\author{
Wilfridus Beda Nuba Dosinaeng*1, Kristoforus Djawa Djong², Samuel Igo Leton³, Meryani Lakapu, \\ Yohanes Ovaritus Jagom5 ${ }^{5}$ Irmina Veronika Uskono6 \\ 1,2,3,4,5,6Program Studi Pendidikan Matematika, Fakultas Keguruan dan Ilmu Pendidikan, Universitas \\ Katolik Widya Mandira \\ *e-mail: wilfridusdosinaeng@gmail.com ${ }^{1}{ }_{2}$ djongdeflores@gmail.com ${ }^{2}$, letonsamuel@gmail.com ${ }^{3}$, \\ Meryanilakapu@gmail.com ${ }^{4}$ kraengyovanmgr@gmail.com $^{5}$, veniuskono@gmail.com ${ }^{6}$
}

\begin{abstract}
This Activities is based on the previous analyzes about the performance of teachers in understanding geometry concepts. These results reveal facts about the difficulty of teachers in understanding and teaching geometry conceptually. Based on these findings, the aims of these activities were of deepening understanding of concepts and training teachers to teach geometry conceptually. This activity is focused on five sub-activities, namely: a) refreshment of geometrical concepts; b) repaired teacher's misconceptions about geometry; c) reinforcement of teachers' understanding of the concept of geometry; d) enrichment; and e) the making and practice of using instructional media to overcome the difficulties of teachers in teaching conceptual geometry to their students conceptually. This activity went well, seen from the presence of the teachers to participate in activities that exceeded the initial target and based on the questionnaire distributed, 88.5\% of participants stated that they were satisfied with this activity.
\end{abstract}

Keywords: Geometry, Conceptual Understanding, Learning Media, Manipulative Media

\begin{abstract}
Abstrak
Kegiatan Pengabdian kepada Masyarakat (PkM) ini didasarkan pada hasil analisis sebelumnya tentang performa para guru dalam memahami konsep geometri. Hasil tersebut mengungkap fakta tentang kesulitan para guru dalam memahami dan mengajarkan konsep geometri secara konseptual kepada siswasiswanya. Berdasarkan temuan tersebut, kegiatan PkM dilaksanakan dengan tujuan untuk memperdalam pemahaman konsep dan melatih cara yang dapat digunakan para guru untuk mengajarkan geometri secara konseptual. Kegiatan ini difokuskan dalam lima sub-kegiatan yaitu: a) penyegaran kembali konsep-konsep geometri; b) perbaikan miskonsepsi yang telah dilakukan berdasarkan hasil analisis sebelumnya; c) penguatan terhadap pemahaman para guru tentang konsep geometri; d) pengayaan; dan e) pembuatan dan Latihan penggunaan media pembelajaran untuk mengatasi kesulitan para guru dalam mengajarkan konsep geometri kepada para siswanya secara konseptual. Kegiatan ini berjalan dengan baik, terlihat dari kehadiran para guru untuk mengikuti kegiatan yang melebihi target awal dan berdasarkan angket yang disebarkan, 88,5\% peserta menyatakan bahwa mereka merasa puas dengan kegiatan ini.
\end{abstract}

Kata kunci: Geometri, Pemahaman Konsep, Media Pembelajaran, Media Manipulatif

\section{PENDAHULUAN}

Salah satu aspek penting dalam belajar yaitu pemahaman. Pemahaman merupakan hasil dari suatu proses yang dicirikan dengan kemampuan seseorang dalam mendeskripsikan, memberikan contoh, menginterpretasi, dan menguraikan sesuatu secara jelas (Mawaddah \& Maryanti, 2016). Pemahaman tentang suatu konsep adalah hasil dari proses-proses atau tindakan-tindakan untuk memahami konsep tersebut secara terperinci (Eriana, Kartono, \& Sugianto, 2019). Untuk memperoleh pemahaman, seseorang harus mengetahui komponenkomponen dari konsep-konsep yang dipelajari dan mengoneksikannya dengan konsep yang sudah dipahami sebelumnya guna membentuk struktur pengetahuan yang baru dan memahami konsep yang dipelajari (Cai \& Ding, 2015).

Secara umum, pemahaman tentang suatu konsep dapat dibagi atas 2 yaitu pemahaman prosedural dan pemahaman konseptual. Fatqurhohman (2016) menjelaskan pemahaman prosedural sebagai kemampuan memecahkan masalah dengan menggunakan prosedur-prosedur yang tepat dan akurat, sedangkan pemahaman konseptual adalah kemampuan 
mengklasifikasikan objek-objek yang menyusun suatu konsep, menyajikan konsep dalam berbagai bentuk representasi, dan menghubungkan konsep-konsep. Hampir serupa, Laswadi, Kusumah, Darwis, \& Afgani (2016) menjelaskan pemahaman konseptual sebagai pemahaman tentang ide-ide matematis sebagai suatu sistem yang terintegrasi dan fungsional, sedangkan pemahaman prosedural sebagai pemahaman tentang prosedur dan pengaplikasian prosedur itu dalam pemecahan masalah. Kedua jenis pemahaman ini saling bersinergi satu sama lain dalam membentuk pemahaman konsep matematis seseorang.

Peran utama seorang guru matematika dalam mengajar yaitu membantu para siswanya untuk dapat membangun pemahaman matematisnya dengan baik baik itu secara prosedural maupun konseptual. Minarni, Napitupulu, \& Husein (2016) menjelaskan bahwa tujuan seseorang mempelajari ilmu matematika yaitu untuk mengembangkan dan memperdalam pemahaman konsep matematis miliknya. Dengan pemahaman, siswa akan mampu mengembangkan pengetahuan matematisnya ke jenjang yang lebih tinggi. Ketika dihadapkan dengan situasi-situasi matematis, siswa yang belajar matematika dengan pemahaman akan mampu melihat karakteristik dari situasi-situasi tersebut secara lebih mendalam, lebih cepat dalam mencari informasi-informasi spesifik dari situasi-situasi matematis yang diberikan, dan menggambarkannya secara mental di dalam pikirannya (Barmby, Harries, Higgins, \& Suggate, 2007). Pemahaman konsep yang baik akan berimplikasi pada terjalinnya konsep-konsep matematis yang dipelajari sebagai satu kesatuan yang tidak terpisahkan satu sama lain di dalam pikiran siswa. Ini merupakan kemampuan yang perlu dimiliki siswa untuk menjadi seorang pemecah masalah yang baik.

Pernyataan terakhir di atas mengimplistkan pemahaman konsep matematis sebagai bagian dari kemampuan pemecahan masalah matematis. National Council of Teacher of Mathematics menjelaskan bahwa tujuan pembelajaran matematika dewasa ini yaitu membentuk para siswa menjadi pemecah masalah yang unggul (NCTM, 2000). Pemahaman konsep matematis yang baik akan membantu siswa dalam mengembangkan kemampuan pemecahan masalah miliknya. Ketika dihadapkan dengan suatu masalah matematis, siswa yang memiliki pemahaman konsep yang baik akan mampu memahami masalah yang diberikan secara lebih mendalam, mengaitkannya dengan jaringan konsep matematis di dalam pikirannya, memilih skema yang tepat, dan kemudian menggunakannya untuk memecahkan masalah yang dihadapi. Sejalan dengan ini, Williams (2011) menyatakan bahwa pemahaman konsep akan sangat membantu seorang pemecah masalah dalam memeriksa kesalahan dari pekerjaannya sendiri dan memperluas pengetahuannya. Tanpa pemahaman yang baik, seseorang akan mengalami kesulitan dalam menganalisis situasi-situasi yang diberikan dan mengaitkannya dengan konsepkonsep matematis yang telah dipelajari untuk memecahkan masalah yang ada.

Pentingnya pemahaman konsep matematis ini kemudian berbanding terbalik dengan fakta di lapangan yaitu para siswa sering mengalami kesulitan dalam membangun pemahaman konsep matematisnya. Konsep-konsep matematika sering dipelajari secara terpisah tanpa ada upaya untuk membangun koneksi antar konsep tersebut. Hal ini bertolak belakang dengan ciri matematika sebagai mata pelajaran yang tersusun secara hierarkis dan sistematis yaitu konsep yang satu berkaitan erat dengan konsep yang lainnya sehingga perlu dikoneksikan satu sama lain untuk membangun struktur pengetahuan yang kompleks guna memahami matematika. Novitasari (2016) menjelaskan bahwa kesulitan para siswa dalam membangun pemahaman konsep matematisnya ini, selain disebabkan oleh faktor internal, juga dapat disebabkan oleh faktor guru. Selain karena tidak menguasai pendekatan/model/metode/strategi yang digunakan dalam penyampaian materi, penyebab lainnya yaitu karena guru sendiri tidak memahami materi/konsep yang diajarkan. Jika guru tidak memahami materi/konsep yang diajarkan, ia akan menyampaikan konsep secara keliru kepada para siswa. Siswa yang diajarkan secara keliru akan membangun struktur pemahaman yang tidak tepat dari suatu konsep dan hal ini akan berdampak lebih jauh ketika ia mempelajari konsep-konsep matematika selanjutnya.

Kegiatan pengabdian kepada masyarakat ini dilakukan bagi guru-guru SD se-kecamatan Kota Soe, Kabupaten TTS, Nusa Tenggara Timur. Kegiatan ini didasarkan pada hasil analisis 
sebelumnya tentang performa para guru dalam memahami konsep geometri. Konsep ini menjadi sorotan sebab konsep geometri menjadi konsep dasar dalam matematika namun masih banyak guru yang mengalami kesulitan dalam memahami konsep ini. Sebagai contoh, Para guru dapat dengan mudah menentukan luas persegi panjang dan jajar genjang berukuran $5 \times 3$ namun mereka kesulitan dalam menjelaskan mengapa hal tersebut benar secara matematis. Ketika persegi panjang tersebut dirotasi sejauh $45^{\circ}$, sebagian guru menganggap bahwa persegi panjang tersebut telah berubah menjadi bangun belah ketupat karena bentuknya berbeda dari bentuk persegi panjang dan lebih menyerupai bangun belah ketupat. Dalam wawancara selanjutnya, ketika diminta menentukan yang mana rumus luas persegi panjang yang benar, apakah $p \times l$ atau $l \times p$, sebanyak 54\% yang menganggap bahwa $p \times l$ adalah rumus yang benar dan bukan $l \times p$ sebab ini merupakan hasil penemuan para ahli dan tidak bisa diubah. Hal ini menunjukkan bahwa pemahaman para guru tentang konsep-konsep tersebut masih terbatas pada pemahaman prosedural dan belum memahaminya secara konseptual.

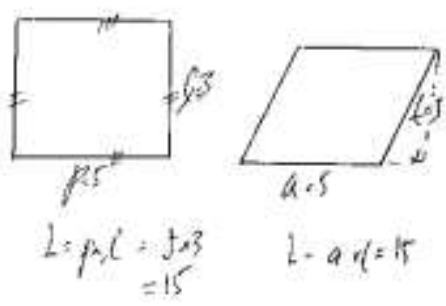

Gambar 1. Jawaban Guru Ketika Ketika Menentukan Luas Persegi dan Jajar Genjang Berukuran $5 \times 3$

Reid \& Reid (2017) menyatakan bahwa guru yang tidak memahami suatu konsep dengan baik akan mengalami kesulitan dalam menjelaskan konsep-konsep tersebut, memodelkannya, membangun koneksi antar konsep yang melibatkan konsep tersebut. Sejalan dengan ini, para guru juga mengemukakan bahwa mereka sering mengalami kesulitan dalam mengajarkan geometri secara konseptual kepada para siswa. Beberapa guru mengungkap bahwa mereka memahami bahwa luas bangun datar adalah jumlah persegi satuan yang dapat menutupi secara utuh bangun datar tersebut, namun mereka mengalami kesulitan dalam menjelaskan hal tersebut kepada para siswa sehingga mereka lebih memilih untuk menunjukkan kepada para siswa rumurumus dan bagaimana rumus-rumus tersebut digunakan dalam pengerjaan soal. Hal ini menyebabkan pemahaman para siswapun pada akhirnya masih terbatas pada pemahaman geometri secara prosedural semata.

Salah satu cara yang dapat digunakan untuk membantu para siswa dalam memahami matematika secara konseptual yaitu dengan menggunakan media pembelajaran. Aditya (2018) menjelaskan media pembelajaran sebagai alat, metode, atau teknik yang dapat digunakan oleh guru untuk mengefektifkan komunikasi dan interaksi di kelas guna mencapat tujuan pembelajaran. Salah satu media pembelajaran yang efektif untuk digunakan di Sekolah Dasar yaitu media manipulatif. Yusof \& Lusin (2013) menjelaskan media manipulatif sebagai modelmodel kongkrit yang melibatkan konsep-konsep matematika, dapat disentuh dan digerakkan dengan tangan, dan menjembatani antara pengalaman kongkrit dan pengetahuan matematis yang bersifat abstrak. Media manipulatif memungkinkan siswa untuk mengeintegrasikan pengetahuan mereka dan mengasosiasikannya dengan pemikirannya guna memahami konsep matematika secara menyeluruh (Kontas, 2016). Secara lebih terperinci, Cockett \& Kilgour (2015) mendeskripsikan manfaat penggunaan media manipulatif dalam pembelajaran matematika di kelas yaitu: 1) menjadikan pembelajaran lebih bermakna; 2) memfasilitasi terciptanya lingkungan belajar yang mendorong keterlibatan dan pemahaman siswa; 3) memenuhi kebutuhan siswa terutama yang memiliki gaya belajar kinestik dan visual; dan 4) membantu peralihan dari pengalaman kongkrit ke penalaran abstrak matematis.

Menyadari bahwa pembelajaran dewasa ini berorientasi pada pembentukkan para siswa menjadi pemecah-pemecah masalah yang handal, para guru ingin memperdalam pemahamannya 
tentang konsep-konsep matematis dan strategi yang dapat mereka lakukan untuk membantu para siswanya agar mampu membangun pemahaman konsep matematisnya. Harapannya yaitu, dengan memperdalam pemahaman konsep matematisnya, para guru dapat membantu para siswa untuk tidak lagi mempelajari konsep-konsep matematis dengan menghafal, namun menemukan sendiri konsep-konsep tersebut melalui pengalaman-pengalaman matematisnya dan menggunakan konsep-konsep tersebut untuk memecahkan masalah. Bertolak dari kebutuhan di atas, Tim Pengabdian Kepada Masyarakat (PkM) memberikan bantuan kepada para guru yang bertujuan untuk memperdalam pemahaman konsep matematis guru-guru SD sekecamatan Kota Soe dan dan melatih para guru dalam mengajar matematika dengan pemahaman melalui pelatihan pembuatan dan penggunaan media pembelajaran.

\section{METODE}

Kegiatan PkM ini dilakukan dengan mempertimbangkan hasil analisis tentang performa para guru Sekolah Dasar se-Kecamatan Kota Soe, Kabupaten TTS, Nusa Tenggara Timur dalam memahami konsep geometri. Dari hasil penelitian tersebut diketahui bahwa: 1) Pemahaman para guru tentang konsep geometri pada umumnya masih terbatas pada pemahaman prosedural; 2) Para guru mengalami kesulitan dalam mengajarkan geometri secara konseptual sehingga dalam praktik pembelajaran di kelas lebih sering meminta para siswa untuk menghafal rumus yang telah ada dan melatih cara pengaplikasian rumus tersebut.

Kegiatan diselenggarakan di SDK Yaswari Soe V dengan pesertanya yaitu guru-guru Sekolah Dasar se-Kecamatan Kota Soe. Sebelum melakukan kegiatan, Tim PkM terlebih dahulu merancang solusi pemecahan masalah sebagai berikut: 1) melakukan kajian Pustaka; 2) merancang susunan materi yang akan dipaparkan pada saat kegiatan PkM; 3) melaksanakan kegiatan PkM menggunakan metode praktik yang terdiri dari kegiatan pendalaman konsep dan pembuatan media pembelajaran yang dapat membantu para guru dalam mengajarkan matematika secara konseptual; 4) evaluasi.

\section{HASIL DAN PEMBAHASAN}

Hasil analisis sebelumnya terkait performa para guru dalam memahami konsep geometri menunjukkan bahwa para guru mengalami kesulitan dalam memahami konsep: a) luas bangun datar; b) persegi dan persegi panjang; dan c) satuan.

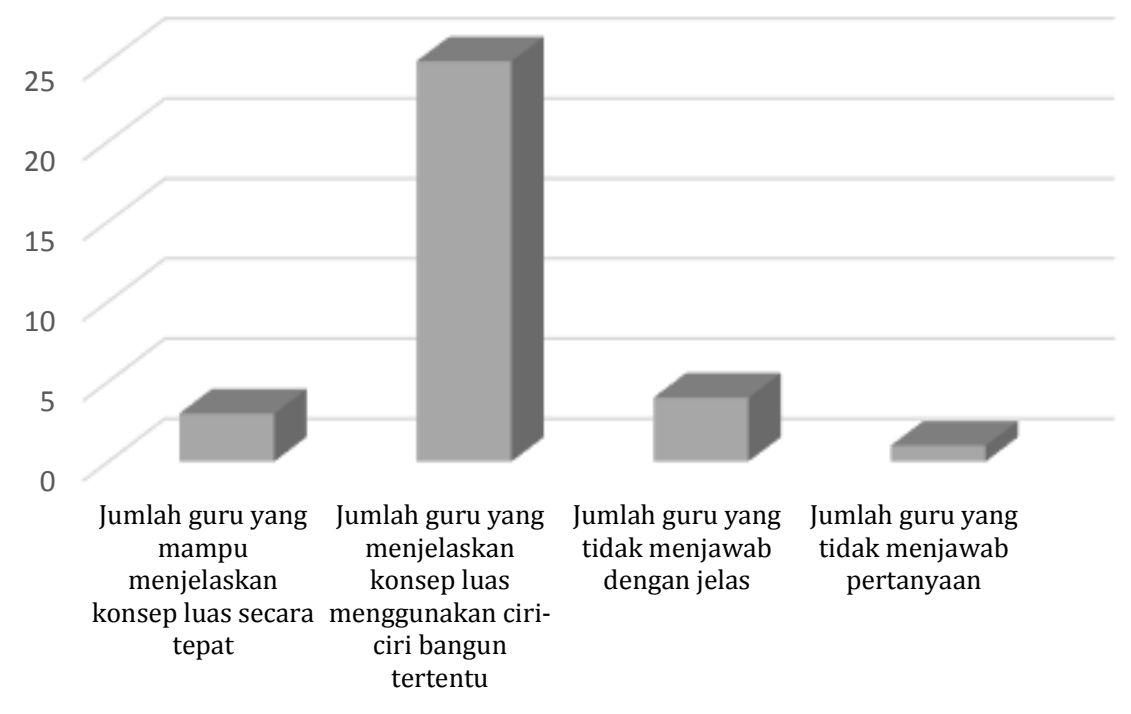

Gambar 2. Kategori Pemahaman Konsep Luas Berdasarkan Hasil Penelitian Sebelumnya 


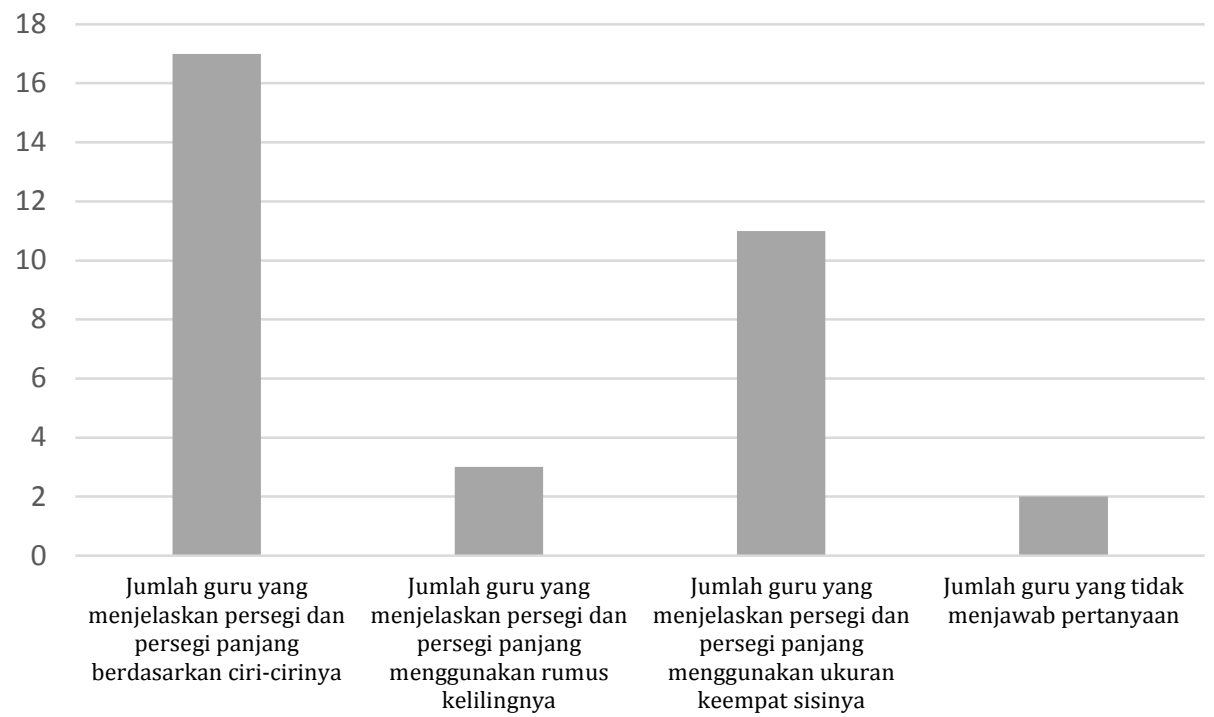

Gambar 3. Kategori Pemahaman Para Guru Tentang Konsep Persegi dan Persegi Panjang Berdasarkan Hasil Penelitian Sebelumnya

Pada Gambar 2 dapat dilihat bahwa hanya 9 orang guru yang mampu menjelaskan konsep luas secara tepat, sedangkan sisanya tidak. Mayoritas para guru menjelaskan konsep luas dengan menyebutkan ciri-ciri dari bangun datar tertentu, seperti luas adalah hasil perkalian panjang dengan lebarnya, atau luas adalah hasil perkalian sisi-sisinya tanpa menjelaskan secara umum pengertian luas bangun datar secara konseptual. Hal ini menunjukkan bahwa pemahaman para guru pada konsep luas masih terbatas pada hafalan rumus-rumus yang dapat digunakan untuk menghitung luas suatu bangun datar. Sedangkan, pada Gambar 3, mayoritas guru menjelaskan pemahaman mereka tentang persegi dan persegi panjang menggunakan ciri-ciri dari persegi dan persegi panjang. Namun, ketika persegi dan persegi panjang tersebut dirotasi sejauh $45^{\circ}$, jawaban para guru pun menjadi beragam terkait bangun yang dibentuk. Sebagian besar guru menganggap bahwa bangun tersebut telah berubah bentuk dari persegi dan persegi panjang menjadi belah ketupat dan layang-layang, Hal ini menunjukkan ketidakpahaman para guru tentang relasi atau hubungan antar bangun datar dalam geometri. Sedangkan berkaitan dengan satuan, hampir semua guru sependapat bahwa pangkat "2" pada satuan luas $\mathrm{cm}^{2}$ adalah hasil dari perkalian $\mathrm{cm} \times$ $\mathrm{cm}$. Hal ini menunjukkan suatu miskonsepsi yang dilakukan oleh para guru berkaitan dengan konsep satuan. Tim PkM berpendapat bahwa jika hal ini tidak segera diperbaiki maka dapat menimbulkan kesalahan konsep yang diajarkan kepada para siswa kelak.

Berdasarkan hasil analisis ini Tim PkM kemudian memutuskan untuk melakukan kegiatan pendalaman konsep geometri bersama para guru tersebut. Kegiatan difokuskan pada temuan hasil analisis yang kemudian dibagi dalam empat kegiatan yaitu: a) penyegaran kembali konsepkonsep geometri; b) perbaikan miskonsepsi yang telah dilakukan berdasarkan hasil analisis sebelumnya; c) penguatan terhadap pemahaman para guru tentang konsep geometri; dan d) pengayaan. Penyegaran konsep dilakukan berkaitan dengan konsep-konsep dasar geometri seperti aksioma titik, garis, dan bidang, hukum kekekalan dalam geometri, sudut dan sisi pada geometri, pengertian luas dan keliling, serta transformasi geometri. Perbaikan miskonsepsi dilakukan berkaitan dengan kesalahan-kesalahan konstruksi konsep yang dilakukan oleh para guru dalam memahami konsep geometri yang telah dianggap sebagai suatu kebenaran. Beberapa miskonsepsi yang diperbaiki pada tahap ini antara lain: a) miskonsepsi tentang bentuk persegi dan persegi panjang yang berubah menjadi belah ketupat dan jajar genjang ketika dirotasi sejauh $45^{\circ}$; b) miskonsepsi tentang luas persegi panjang adalah $p \times l$ dan bukan $l \times p$ sebab hal itu merupakan temuan para ahli yang tidak bisa diubah; $c$ ) miskonsepsi tentang pangkat pada satuan 
luas sebagai hasil kali satuan-satuannya. Sedangkan, penguatan konsep dilakukan antara lain berkaitan dengan: a) pembuktian rumus-rumus geometri; b) hubungan antar bangun datar dalam geometri; dan c) garis-garis istimewa dalam geometri. Untuk memperdalam pemahaman para guru, di tahap akhir dalam kegiatan pendalaman konsep ini para guru dilatih dengan beberapa soal pengayaan untuk membantu para guru dalam melatih kemampuan pemecahan masalahnya berkaitan dengan konsep geometri.
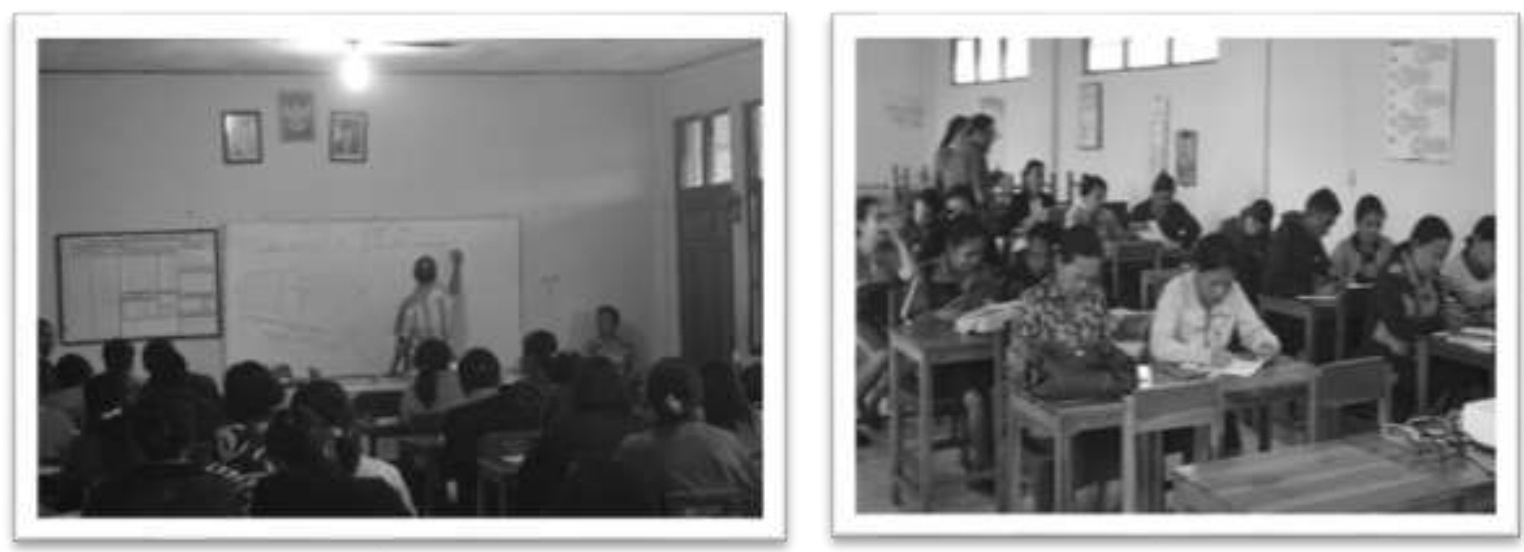

Gambar 4. Kegiatan Pendalaman Konsep Matematis Bersama Para Guru

Untuk mengatasi kesulitan para guru dalam mengajarkan konsep geometri kepada para siswanya secara konseptual, Tim PkM memberikan bantuan berupa pelatihan pembuatan media pembelajaran kepada para guru. Media pembelajaran yang dibuat yaitu media pembelajaran manipulatif berbahan kertas yang mudah dibuat dan digunakan. Pada tahap ini, para guru dilatih membuat media manipulatif sederhana untuk dapat membuktikan konsep-konsep luas bangun datar. Diharapkan dengan menggunakan media tersebut, para siswa dapat memahami bahwa rumus-rumus bangun datar yang mereka pelajari selama ini tidak muncul secara tiba-tiba namun dapat dibuktikan secara matematis dengan menggunakan hukum kekekalan luas dan relasi antar bangun datar yang divisualisasikan dalam media manipulatif yang mereka buat.
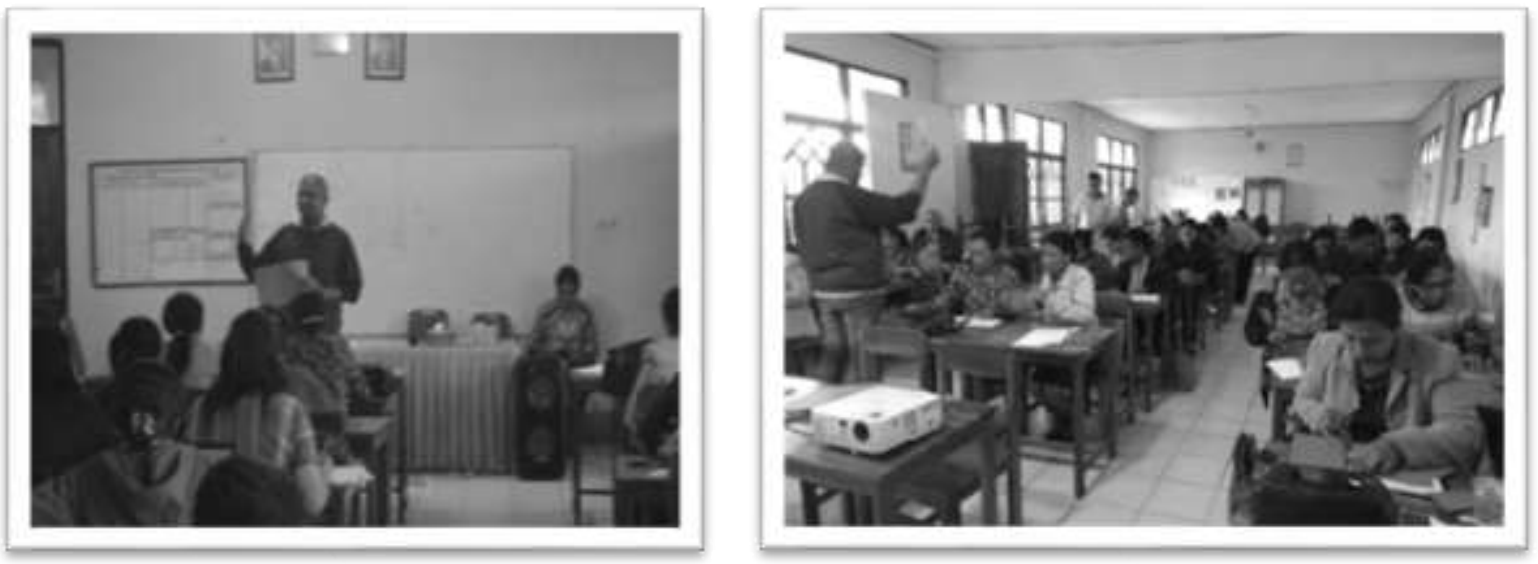

Gambar 5. Pendampingan Para Guru dalam Membuat Media Pembelajaran Manipulatif Berbahan Kertas 


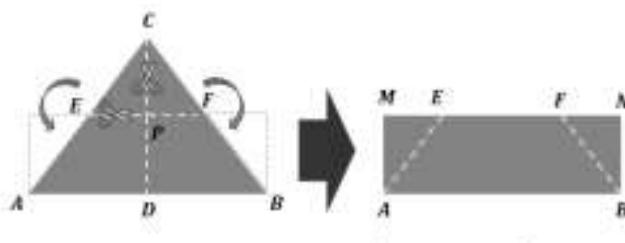

Lutes Segitiga $=A B \times B N=A B \times \frac{1}{2} C D=$ alas $\times \frac{1}{2}$ tinggi $=\frac{1}{2} \times$ alas $\times$ tinggi
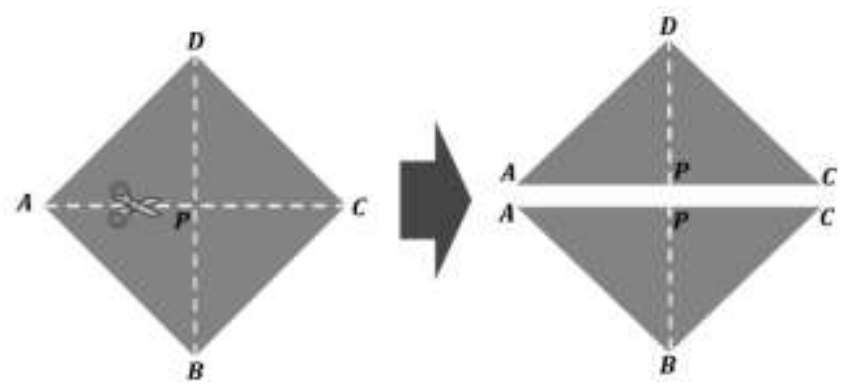

Luas Belah Ketupat ABCD - Luas Segittiga $A D C+$ Luns Segitiga $A B C$ $=\frac{1}{2}(A C \times P B)+\frac{1}{2}(A C \times P D)=\frac{1}{2}(A C \times(P B+P D))=\frac{1}{2}(A C \times B D)$

$=\frac{1}{2} \times$ Diagonal pertama $\times$ Diagonal kedua
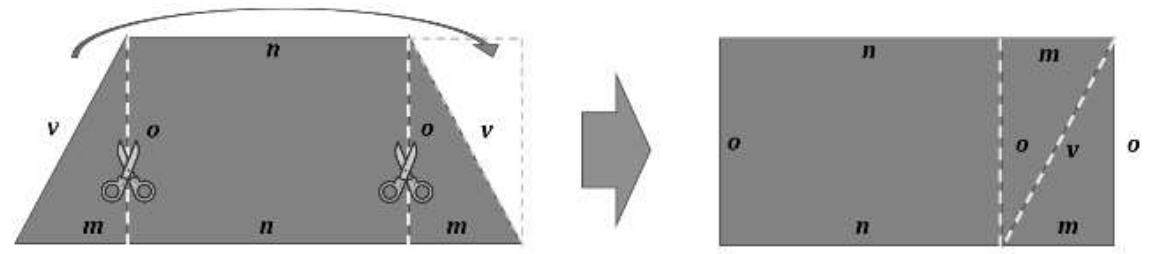

LuasTrapesium $=(m+n) \times o=\frac{2(m+n)}{2} \times o=\frac{((m+n+m)+n) \times o}{2}=\frac{\text { Jumlah sisi sejajar } \times \text { tinggi }}{2}$
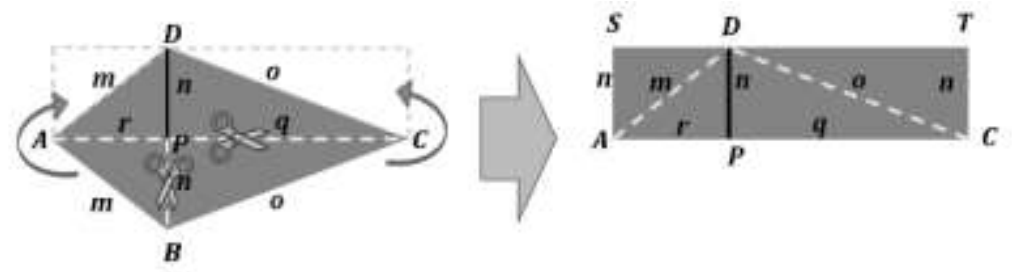

Luas Layang-layang $=A C \times C r=(r+q) \times n=(r+q) \times \frac{n+n}{2}=\frac{1}{2} \times(n+n) \times(r+p)$

$=\frac{1}{2} \times$ Diagonal pertama $\times$ Diagonal kedua
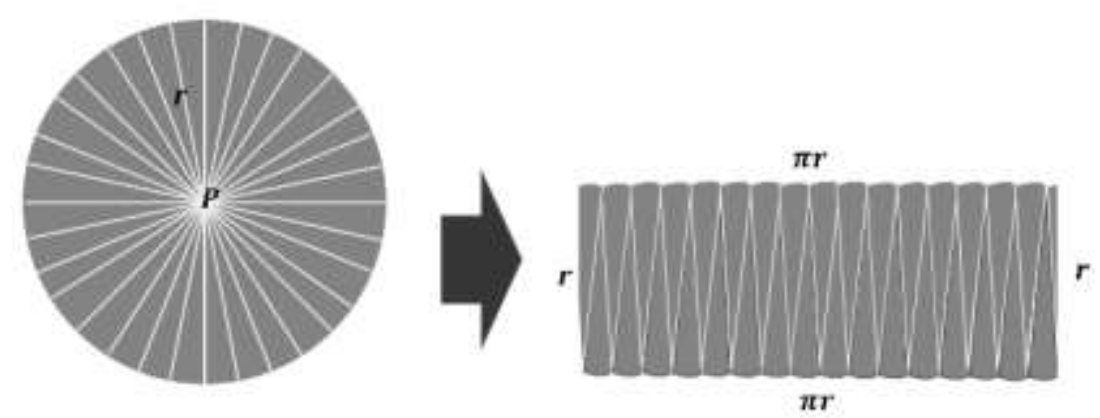

Luas Lingkaran $=\pi r \times r=\pi r^{2}$

Gambar 6. Media Pembelajaran Manipulatif Berbahan Kertas 
Kegiatan PkM yang dilaksanakan pada guru-guru SD di Kecamatan Kota Soe ini berlangsung dengan baik. Hal ini terlihat dari antusias guru dalam mengikuti kegiatan pelatihan sangat tinggi, terbukti dengan kehadiran para guru untuk mengikuti kegiatan melebihi target awal dan berdasarkan angket yang disebarkan, 88,5\% peserta merasa puas dengan kegiatan pelatihan yang diikutinya. Hal ini mengindikasikan bahwa para guru menyambut positif kegiatan yang telah dilakukan.

Kegiatan ini bisa berjalan dengan baik karena didukung pula oleh beberapa faktor antara lain: (1) para guru sangat antusias dalam mengikuti kegiatan ini; (2) lokasi kegiatan strategis; (3) adanya kerjasama yang baik antara Tim PkM dan Dinas P dan K Kab. TTS, sehingga kegiatan dapat berjalan dengan lancar. Sedangkan, kendala yang dialami selama kegiatan antara lain: kurangnya alat dan bahan pembuatan alat peraga, hal ini disebabkan karena kehadiran guru yang melebihi target peserta.

\section{KESIMPULAN}

Kegiaan PkM ini dilakukan berdasarkan hasil analisis tentang performa para guru dalam memahami konsep geometri. Berdasarkan kegiatan Pengabdian Kepada Masyarakat yang telah dilaksanakan tim dapat menyimpulkan hal-hal sebagai berikut:

a. Kegiatan pendalaman konsep dan pelatihan pembuatan media pembelajaran kepada guruguru SD se-Kecamatan Kota Soe terlaksana dengan baik. Hal ini terlihat dari kehadiran para guru untuk mengikuti kegiatan yang melebihi target awal dan berdasarkan angket yang disebarkan, 88,5\% peserta merasa puas dengan kegiatan ini;

b. Kegiatan pelatihan pembuatan alat peraga yang dilakukan membuka pola pikir guru tentang luas bangun datar, terkhususnya tentang asal-usul dari luas beberapa bangun datar,

\section{UCAPAN TERIMA KASIH}

Tim PkM mengucapkan terima kasih kepada pihak Universitas Katolik Widya Mandira yang telah memberi dukungan financial terhadap pengabdian ini.

\section{DAFTAR PUSTAKA}

Aditya, P. T. (2018). Pengembangan Media Pembelajaran Matematika Berbasis Web Pada Materi Lingkaran Bagi Siswa Kelas Viii. Jurnal Matematika Statistika Dan Komputasi, 15(1), 64. https://doi.org/10.20956/jmsk.v15i1.4425

Barmby, P., Harries, T., Higgins, S., \& Suggate, J. (2007). How can we assess mathematical understanding? Proceedings of the 31st Conference of the International Group for the Psychology of Mathematics Education, 2, 41-48.

Cai, J., \& Ding, M. (2015). On mathematical understanding: perspectives of experienced Chinese mathematics teachers. Journal of Mathematics Teacher Education, 18(5), 5-29. https://doi.org/10.1007/s10857-015-9325-8

Cockett, A., Kilgour, P. W., Cockett, A., \& Kilgour, P. (2015). Mathematical Manipulatives: Creating an Environment for Understanding, Efficiency, Engagement , and Enjoyment Mathematical manipulatives: Creating an environment for understanding, efficiency, engagement, and enjoyment. Teach Collection of Christian Education, 1(1), 47-54.

Eriana, Kartono, \& Sugianto. (2019). Understanding Ability of Mathematical Concepts and Students' Self-reliance towards Learning by Implementing Manipulative Props (APM) on Jigsaw Technique. Journal of Primary Education, 8(2), 176-183.

Fatqurhohman, \& Fatqurhohman. (2016). Transition Process of Procedural to Conceptual Understanding in Solving Mathematical Problems. International Education Studies, 9(9), 182. https://doi.org/10.5539/ies.v9n9p182

Kontas, H. (2016). The Effect of Manipulatives on Mathematics Achievement and Attitudes of Secondary School Students. Journal of Education and Learning, 5(3), 10. 
https://doi.org/10.5539/jel.v5n3p10

Laswadi, Kusumah, Y. S., Darwis, S., \& Afgani, J. D. (2016). Developing conceptual understanding and procedural fluency for Junior High School students through model-facilitated learning (MFL). European Journal of Science and Mathematics Education, 4(1), 67-74. Retrieved from http://libproxy.library.wmich.edu/login?url=https://search.proquest.com/docview/1826 544232?accountid=15099

Mawaddah, S., \& Maryanti, R. (2016). Kemampuan Pemahaman Konsep Matematis Siswa SMP dalam Pembelajaran Menggunakan Model Penemuan Terbimbing (Discovery Learning). EDU-MAT: Jurnal Pendidikan Matematika, 4(1), 76-85. https://doi.org/10.20527/edumat.v4i1.2292

Minarni, A., Napitupulu, E. E., \& Husein, R. (2016). Mathematical understanding and representation ability of public junior high school in North Sumatra. Journal on Mathematics Education, 7(1), 43-56. https://doi.org/10.22342/jme.7.1.2816.43-56

NCTM. (2000). Principles and Standards and for School Mathematics. United States of America: The National Council of Teachers of Mathematics, Inc.

Novitasari, D. (2016). Pengaruh Penggunaan Multimedia Interaktif Terhadap Kemampuan Pemahaman Konsep Matematis Siswa. FIBONACCI: Jurnal Pendidikan Matematika Dan Matematika, 2(2), 8. https://doi.org/10.24853/fbc.2.2.8-18

Reid, M., \& Reid, S. (2017). Learning to be a math teacher: What knowledge is essential? International Electronic Journal of Elementary Education, 9(4), 851-872.

Williams, H. R. A. (2011). A conceptual framework for student understanding of logarithms (Brigham Young University). Retrieved from https://scholarsarchive.byu.edu/etd/3123

Yusof, J., \& Lusin, S. (2013). The role of manipulatives in enhancing pupils' understanding on fraction concepts. International Journal for Infonomics, 6(3/4), 750-755. https://doi.org/10.20533/iji.1742.4712.2013.0087 